\title{
Investigation of the Effect of Cutting Parameters on the Surface Roughness Value in the Machining of AISI 4140 Steel with Taquchi Method
}

\section{Oğur IYYNEN ${ }^{1}$, Abidin ŞAHİNOĞLU², Mustafa ÖZDEMIR ${ }^{3}$, Volkan YILMAZ ${ }^{4}$}

\begin{abstract}
AISI 4140 steel material has a wide range of usage in the industry. Before this material is hardened, rough turning is performed. Besides the surface roughness value is very important in terms of machinability. In this experimental study, the effect of cutting parameters on surface roughness (Ra and Rz) during the turning of AISI 4140 steel was analyzed using the Taguchi method. This study, Taguchi L9 was designed in 3 different cutting speeds (100, 140 and $180 \mathrm{~m} \mathrm{~min}^{-1}$ ), 3 different feed rates $\left(0.08,0.12\right.$ and $\left.0.16 \mathrm{~mm} \mathrm{rev}^{-1}\right)$, and 3 different depth of cut $(0.5,0.9$ and $1.3 \mathrm{~mm})$. In the analysis of experimental data, $\mathrm{S} / \mathrm{N}$ (signal/noise) ratios and variance analysis were used to analyze the effect of cutting parameters on the surface roughness value. The degrees of influence on $\mathrm{Ra}$ according to $\mathrm{S} / \mathrm{N}$ ratios are the feed rate $(\boldsymbol{f})$, cutting speed $(\boldsymbol{V})$, and depth of cut $(\boldsymbol{a})$, respectively, from large to small. On $\mathrm{Rz}$, the effects of cutting parameters respectively were observed to be in $\boldsymbol{f}, \boldsymbol{a}$, and $\boldsymbol{V}$. The $\boldsymbol{f}$ on surface roughness values ( $\mathrm{Ra}$ and $\mathrm{Rz}$ ) was found to have an effect of $99.34 \%$ and $98.47 \%$, respectively.
\end{abstract}

Keywords: Taguchi method, Surface roughness, Machinability

\footnotetext{
${ }^{1}$ Oğur IYNEN (Orcid ID: 0000-0003-1096-1836), Bozok University, Faculty of Engineering, Mechanical Engineering, Yozgat, Turkey

${ }^{2}$ Abidin ŞAHINOĞLU (Orcid ID: 0000-0003-0040-442X), Department of Mechanical and Metal Technology, Çankırı Karatekin University, Çankırı, Turkey,

${ }^{3}$ Mustafa ÖZDEMIR (Orcid ID: 0000-0002-7340-0940, Department of Machine and Metal Technology, Vocational School of Technical Sciences, Yozgat Bozok University, Yozgat,

${ }^{4}$ Volkan YILMAZ (Orcid ID: 0000-0002-8937-6527), Gazi University, Faculty of Technology, Manufacturing Engineering, Ankara, Turkey

*Sorumlu Yazar/Corresponding Author: Mustafa ÖZDEMIR, e-mail: mustafa.ozdemir@bozok.edu.tr 


\section{INTRODUCTION}

With the development of technology, in addition to dimensional integrity, surface quality has emerged as an important factor in modern metal removal methods. With the advances in machine technologies, it has required its machines to be more efficient. Thus, the lifetimes of the machines are extended and these machines provide lower energy consumption during their operation. It is provided with low surface roughness in the machines with lower energy consumption and longer machine life. An important indicator of surface quality is the low surface roughness value. Therefore, it is desired to have a low surface roughness value especially in machine parts that contact each other. A good surface quality ensures that the friction force is reduced in machine parts that come into contact with each other. Thus, the amount of friction-related wear decreases on the surfaces moving inside each other. Temperature formation is minimized with low friction. Therefore, not only energy loss is reduced, but the machines are provided to work properly. Because of the decrease in temperature, less expansion occurs in the machine parts. Expansion in machine parts can cause machines to become unusable. Therefore, friction and temperature in machine parts are undesirable. This is the main reason why surface roughness value is important in the machining process. In turn, it is important to select the appropriate cutting parameters to achieve high cutting performance and dimensional accuracy. Selecting appropriate cutting parameters in machining depends on the tool-workpiece material pair, cutting conditions, machine tool, and cutting tool (Daim et al., 2008; Shaw, 1984; Nalbant and Gökkaya, 2007; Asiltürk and Akkuş, 2011; Das et al., 2017; Das et al., 2015; Motorcu et al., 2016). The cutting parameters affect the surface roughness, surface structure, and dimensional deviations of the machine part. Surface roughness is the result of cutting parameters such as tool geometry (tool radius, edge geometry, angle, etc.) and cutting parameters ( $\boldsymbol{V}, \boldsymbol{f}, \boldsymbol{a}$, etc.) (Özel and Karpat, 2005; Chavoshi and Tajdari, 2010). Generally, cutting parameters are tried to be obtained by using the trial and error method for the desired dimensional accuracy. However, these processes increase the machining times and increase workplace costs. When the researches investigate in recent years are examined, the Taguchi technique and response surface method (RSM) are used differently from these methods. Thus, by trying a minimum number of experiments, optimum cutting parameters were determined. Reis et al. analyzed the wear behavior and cutting performance of coated cermet insert and carbide inserts in turning of AISI 4140 steel using variance analysis (Reis et al.,2019). Şahinoğlu and Rafighi examined the machinability properties of AISI 4140 material. In the study, the effect of cutting parameters on vibration, sound intensity, current value, and surface roughness value was investigated. According to the results of the experiment, it has been determined that the most effective parameter on the surface roughness is the $f$. (Şahinoğlu and Rafighi, 2020). Suresh et al. investigated the effect of $\boldsymbol{V}, \boldsymbol{f}, \boldsymbol{a}$ and cutting time in turning of AISI 4340 hardened steel on cutting forces, tool wear and surface roughness by using RSM (Suresh et al., 2012). Hessainia et al. conducted a study on the estimation of surface roughness in turning processes of $42 \mathrm{CrMo} 4$ material on cutting parameters and tool vibration. The surface roughness model was prepared by using RSM (Hessainia et al., 2013). Asilturk and Çunkaş carried out a study on estimating and modeling of surface roughness during turning operations using artificial neural networks and multiple regression method (Asiltürk and Çunkaş, 2011). Yadav et al; examined the effects of AISI 1045 material on the surface roughness value in CNC turning. In the study, Taguchi L27 experimental design, signal/noise ratio, and ANOVA were used in analyzing the data (Yadav et al., 2012). Gunay, In the process of turning AISI 316L material, the effect of cutting parameters on cutting force and surface roughness value was analyzed. The experiment was designed with Taguchi L9 and the effects of cutting parameters were analyzed with the help of ANOVA (Günay, 2013). 
It is very important to determine the optimum cutting parameters according to the relationship between the insert, workpiece material, and cutting parameters in machining. Therefore, despite the many studies, the effect of cutting parameters on the surface roughness value is still an important research subject in the machining of AISI 4140 material with TCMT 16T304 NN LT 1000 insert. In this experimental study, the effect of parameters on surface roughness values was analyzed using the Taguchi L9 orthogonal array. The effects of cutting parameters on surface roughness values were determined by using $\mathrm{S} / \mathrm{N}$ ratios and variance analysis. Optimization was completed by determining the optimum cutting parameters.

In this experimental study, the effect of cutting parameters on surface roughness values was examined in detail. AISI 4140 steel material is generally preferred in hard turning operations. Therefore, very low feed, depth of cut and cutting speed are preferred. however, since most of the turning was the part of the material before hardening, the material without heat treatment was processed in this experimental study. Thus, it is aimed to make a new contribution to the existing literature studies by expanding the processing conditions of AISI 4140 Steel.

\section{MATERIALS AND METHODS}

\section{Materials}

In this experimental study, the effect of cutting parameters on the surface roughness (Ra and Rz) of the AISI 4140 steel on the CNC lathe was analyzed using the Minitab 16.0 software program. The chemical composition of the material used in the experimental study is shown in Table 1.

Table 1. Chemical composition of AISI 4140 steel used in the experiments.

\begin{tabular}{lc}
\hline Constituent & Percentage present (\%) \\
\hline $\mathrm{C}$ & 0.41 \\
$\mathrm{Mn}$ & 0.83 \\
$\mathrm{Si}$ & 0.21 \\
$\mathrm{Cr}$ & 0.9 \\
$\mathrm{~S}$ & 0.026 \\
$\mathrm{P}$ & 0.029 \\
$\mathrm{Mo}$ & 0.18 \\
\hline
\end{tabular}

\section{Experimental procedure}

In turning experiments, CNC lathe with GOODWAY GS-260Y model in engine power of $15 \mathrm{~kW}$ was used. In turning tests, TCMT 16T304 NN LT 1000 inserts made by the LAMINA Technology Company were used together with TTJNL 2525 M16 type tool holder. In cutting tools, tool radius and feed rate are the most effective parameters on the surface roughness value. In this experimental study, the cutting tool with a $0.4 \mathrm{~mm}$ tip radius was preferred. Tools with low tip radii have lower strength. but suitable for machining low strength steels. Low tip radius provides low radial forces. Tools with low tool radii are particularly preferred at low depths of cut. Therefore, it is machined with tool with $0.4 \mathrm{~mm}$ tool radius in non-hardened AISI 4140 steel material. The tool used was preferred because it provides a good cutting by minimizing chip and tool friction due to the TIN Coating. Also, since the hardness of the workpiece material was not high, a very good tool performance was obtained with coated carbide tools. This tool was preferred to obtain a good surface quality with long tool life. The workpiece length is $240 \mathrm{~mm}$ and the machined diameter is $80 \mathrm{~mm}$, it is machined by connecting between the chuck and the tailstock. In the experimental study, while doing 9 experiments, it is aimed to keep the diameter unchanged and to perform a constant speed for the same cutting speed. 9 experiments were carried out 
on the workpiece surface at a distance of $20 \mathrm{~mm}$. Therefore, the total length $240 \mathrm{~mm}$ was chosen. Thus, a distance of $180 \mathrm{~mm}$ was machining. The experiments are carried out by dry turning without the use of coolant. Therefore the cooling fluid's harmful effect has been minimized. Besides, in the coated tool, AISI 4140 low friction force that occurs while machining the material reduces the temperature formation. Therefore, machining experiments have been carried out without the use of coolant. The test setup and surface roughness measuring device used in the experimental study are shown in Figure 1. For average surface roughness measurements, the Mitutoyo SJ-400 model surface roughness measuring device was used. Due to the turning standard, 3 samples were taken from each sample, 5 measurements were taken for each surface roughness value, and the values were obtained by calculating the arithmetic mean. Surface roughness was measured according to ISO 4287 standard (According to ISO 4287 standard, the cut-off length of $\lambda \mathrm{c}=0.8 \mathrm{~mm}$ was chosen because the maximum $f$ was $0.16 \mathrm{~mm} \mathrm{rev}^{-1}$ (between 0.13-0.4 $\mathrm{mm} \mathrm{rev}^{-1}$ ).

The profile roughness parameters device was calibrated at certain intervals before the measurement. Calibration value was made according to the roughness block with $\mathrm{Ra}=2.94 \mu \mathrm{m}$. Profile roughness measurement was made on the workpiece in $15 \mathrm{~mm}$ length. Therefore, the distance of the cut of length was determined as 0.8 . Measurements were made in three different points by rotating the workpiece. Average $\mathrm{Ra}$ and $\mathrm{Rz}$ values were obtained by taking the arithmetic averages of these measurements.

The Taguchi experiment design method is an experimental design method that minimizes the number of experiments that makes experimental studies shorter and easier. The Taguchi method is an experimental design method developed by Dr. Genichi Taguchi. This method has been widely used in the European and American industries after the 1980s. Thanks to this method, the optimization of long and expensive experiments can be done with fewer experiments compared to the full factorial method. Taguchi technique is a method that can determine the effectiveness of the parameters, reduce the duration of the experiment and reduce the cost. While preparing the experimental study plan, the parameters to be used in the experiments and their levels are determined. Then, the system is created by selecting the orthogonal arrays suitable for their degrees of freedom. The $\mathrm{S} / \mathrm{N}$ ratio is converted into performance characteristics for the interpretation of the experimental studies. The most used performance characteristics are the smallest (the smallest, the best), the biggest best (The biggest, the best), and the nominal best (Nominal best). In determining the $\mathrm{S} / \mathrm{N}$ values in this study, since the profile roughness values are desired to be the smallest, the formula corresponding to the "smallest best" principle given in Equation 1 was used (Ross, 1988; Gür et al., 2019; Savaş et al., 2016).

$$
S / N=-10 \cdot \log \left(\frac{1}{n} \cdot \sum_{i=1}^{n} Y_{i}^{2}\right)
$$

In the study, three different $\boldsymbol{V}$ value $\left(100 \mathrm{~m} \mathrm{~min}^{-1}, 140 \mathrm{~m} \mathrm{~min}^{-1}\right.$ and $\left.180 \mathrm{~m} \mathrm{~min}^{-1}\right), \boldsymbol{f}\left(0.08 \mathrm{~mm} \mathrm{rev}^{-}\right.$ ${ }^{1}, 0.12 \mathrm{~mm} \mathrm{rev}^{-1}$ and $\left.0.16 \mathrm{~mm} \mathrm{rev}^{-1}\right)$ and $\boldsymbol{a}(0.5 \mathrm{~mm}, 0.9 \mathrm{~mm}$ and $1.3 \mathrm{~mm})$ were used as cutting parameters. While determining the cutting parameters, the results of the tool catalogs, existing literature studies, and preliminary experiments were used. While the classical method requires $33=27$ experiments, 9 experiments were designed using the Taguchi L9 vertical array (Table 2). 


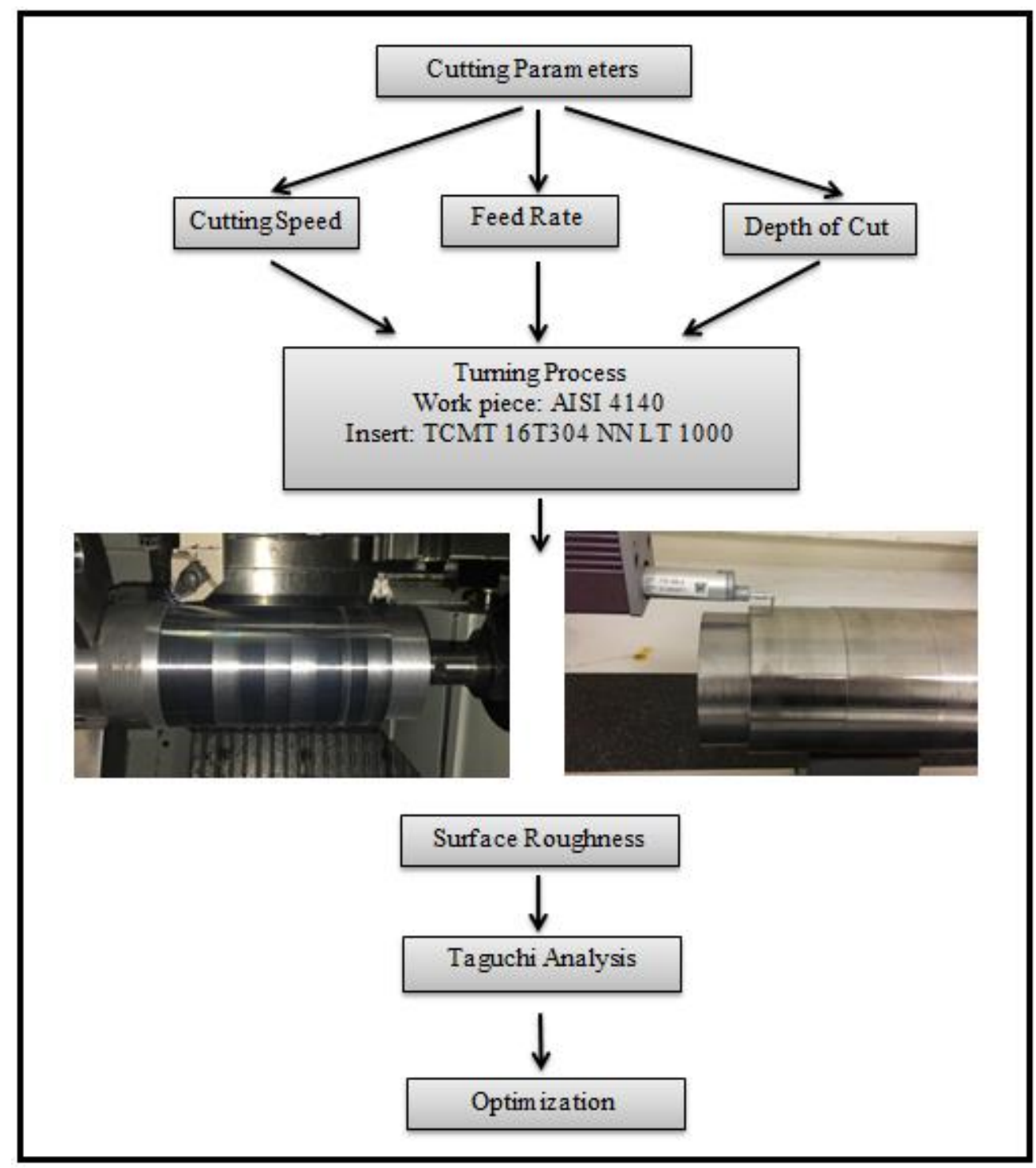

Figure 1. Experimental setup and profile roughness measuring device

Table 2. Cutting parameters and their levels

\begin{tabular}{lccccc}
\hline Factors & Symbol & Unit & Level 1 & Level 2 & Level 3 \\
\hline Cutting speed & $\boldsymbol{V}$ & $\mathrm{m} \mathrm{min}^{-1}$ & 100 & 140 & 180 \\
Feed rate & $\boldsymbol{f}$ & $\mathrm{mm} \mathrm{rev}^{-1}$ & 0.08 & 0.12 & 0.16 \\
Depth of cut & $\boldsymbol{a}$ & $\mathrm{mm}$ & 0.5 & 0.9 & 1.3 \\
\hline
\end{tabular}

\section{RESULTS AND DISCUSSION}

The effect of cutting parameters $(\boldsymbol{V}, \boldsymbol{f}$, and $\boldsymbol{a})$ on the profile roughness during turning of AISI4140 material was analyzed using Taguchi L9 vertical array. Optimum cutting parameters were determined using $\mathrm{S} / \mathrm{N}$ ratios on profile roughness values (Table 3 ). When $\mathrm{S} / \mathrm{N}$ ratios were examined, optimum cutting parameters on profile roughness parameters $\mathrm{Ra}$ and $\mathrm{Rz}$ were determined as at $180 \mathrm{~m} \mathrm{~min}^{-1}$ cutting speed (V3), $0.08 \mathrm{~mm} \mathrm{rev}^{-1}$ feed rate (f1), and $1.3 \mathrm{~mm}$ depth of cut (a3). $\mathrm{S} / \mathrm{N}$ ratios of profile roughness values obtained in optimum cutting parameters were determined as $\mathrm{Ra} S / \mathrm{N}=-1.58362$ and $\mathrm{Rz} \mathrm{S} / \mathrm{N}=$ 16.3909. In the cutting parameter V3-f3-a2, the maximum $\mathrm{Ra}$ and $\mathrm{Rz}$ values were determined as 2.99 $\mu \mathrm{m}$ and $13.4 \mu \mathrm{m}$, respectively. It was determined that $\mathrm{Ra}$ and $\mathrm{Rz}$ value obtained with cutting parameter V3-f1-a3 decreased the roughness values of $249 \%$ and $203 \%$ compared to the parameter V3-f3-a2. 
Table 3. L9 orthogonal array, results and $\mathrm{S} / \mathrm{N}$ ratios for Profile roughness

\begin{tabular}{cccccccc}
\hline \multirow{2}{*}{ Number of Test } & \multicolumn{2}{c}{ Cutting Parameters } & \multicolumn{2}{c}{ Measured } & \multicolumn{2}{c}{ S/N Ratios } \\
\cline { 2 - 8 } & $\mathbf{V}$ & $\mathbf{f}$ & $\mathbf{a}$ & $\mathbf{R a}(\boldsymbol{\mu m})$ & $\mathbf{R z}(\boldsymbol{\mu m})$ & $\mathbf{R a}(\mathbf{d B})$ & $\mathbf{R z}(\mathbf{d B})$ \\
\hline $\mathbf{1}$ & 100 & 0.08 & 0.5 & 1.32 & 7.3 & -2.41148 & -17.2665 \\
$\mathbf{2}$ & 100 & 0.12 & 0.9 & 2.07 & 9.4 & -6.31941 & -19.4626 \\
$\mathbf{3}$ & 100 & 0.16 & 1.3 & 2.97 & 13 & -9.45513 & -22.2789 \\
$\mathbf{4}$ & 140 & 0.08 & 0.9 & 1.31 & 7.3 & -2.34543 & -17.2665 \\
$\mathbf{5}$ & 140 & 0.12 & 1.3 & 2.12 & 9.5 & -6.52672 & -19.5545 \\
$\mathbf{6}$ & 140 & 0.16 & 0.5 & 2.9 & 12.8 & -9.24796 & -22.1442 \\
$\mathbf{7}$ & 180 & 0.08 & 1.3 & 1.2 & 6.6 & $\mathbf{- 1 . 5 8 3 6 2}$ & $\mathbf{- 1 6 . 3 9 0 9}$ \\
$\mathbf{8}$ & 180 & 0.12 & 0.5 & 2.06 & 9.1 & -6.27734 & -19.1808 \\
$\mathbf{9}$ & 180 & 0.16 & 0.9 & 2.99 & 13.4 & -9.51342 & -22.5421 \\
\hline
\end{tabular}

The radius of the tool used is $0.4 \mathrm{~mm}$. The recommended $f$ for a good surface is $1 / 4$ of the tool radius. Therefore, the $f$ should not exceed $0.4 / 4=0.1 \mathrm{~mm} \mathrm{rev}^{-1}$. Therefore, an excessive increase in profile roughness of $0.16 \mathrm{~mm} \mathrm{rev}^{-1}$ was observed. In this experimental study, this roughness value can also be accepted as the rough turning is done. On profile roughness values ( $\mathrm{Ra}$ and $\mathrm{Rz}$ ), the effect levels of the cutting parameters $\mathrm{S} / \mathrm{N}$ are shown in Table 4 and Table 5 . When Table 4 is examined, it was determined that the level 3 of cutting speed (V3) was effective at the rate of $\mathrm{S} / \mathrm{N}-5,791 \mathrm{~dB}$, level 1 of feed rate (f1) $-2,114 \mathrm{~dB}$ and level 3 of depth of cut (a3) $-5,855 \mathrm{~dB}$. According to the L9 orthogonal array, the optimum cutting parameters on Ra were determined as V3-f1-a3. The impact values of the cutting parameters on $\mathrm{Ra}$ are in order of importance from bigger to small; $\boldsymbol{f}$ was determined as $\boldsymbol{V}$ and $\boldsymbol{a}$. The effect of the $f$ is the most on the profile roughness values. Because the increase in the $f$ increases the height between the helix canals and the pits. Therefore, the profile roughness value is high. Optimum cutting parameters on Rz value Level 3 of cutting speed (V3, S/N : -19.66 dB), level 1 of feed rate (f1, $\mathrm{S} / \mathrm{N}:-2.114 \mathrm{~dB})$ and level 3 of depth of cut (a3, S/N : -19.41 dB) (V3-f1-a3). The significance of cutting parameters on $\mathrm{Rz}$ was determined as the $\boldsymbol{f}, \boldsymbol{a}$ and $\boldsymbol{V}$, respectively (Table 5).

Table 4. Response Table for S/N Ratios for Ra

\begin{tabular}{cccccc}
\hline Factors & Level 1 & Level 2 & Level 3 & Delta( $\boldsymbol{\delta})$ & Rank \\
\hline $\mathbf{V}\left(\mathbf{m ~ m i n}^{-1}\right)$ & -6.062 & -6.040 & -5.791 & 0.271 & 2 \\
$\mathbf{f}\left(\mathbf{m m ~ r e v}^{-1}\right)$ & -2.114 & -6.374 & -9.406 & 7.292 & 1 \\
$\mathbf{a}(\mathbf{m m})$ & -5.979 & -6.059 & -5.855 & 0.204 & 3 \\
\hline
\end{tabular}

Table 5. Response Table for S/N Ratios for Rz

\begin{tabular}{cccccc}
\hline Factors & Level 1 & Level 2 & Level 3 & Delta $(\boldsymbol{\delta})$ & Rank \\
\hline $\mathbf{V}\left(\mathbf{m ~ m i n}^{-1}\right)$ & -19.67 & -19.66 & -19.37 & 0.30 & 3 \\
$\mathbf{f}\left(\mathbf{m m ~ r e v}^{-1}\right)$ & -16.97 & -19.40 & -22.32 & 5.35 & 1 \\
$\mathbf{a}(\mathbf{m m})$ & -19.53 & -19.76 & -19.41 & 0.35 & 2 \\
\hline
\end{tabular}

The contribution rates of the cutting parameters on the profile roughness parameters ( $\mathrm{Ra}$ and $\mathrm{Rz}$ ) are shown in Table 6. When the table is analyzed, it was determined as a result of ANOVA, that the $f$ on the Ra and Rz was the most effective factor. The effects of $f$ were $99.39 \%$ and $98.47 \%$ respectively on the profile roughness. When the semantic value was examined in terms of $\mathrm{p}<0.05$, the $f$ was significant, while the $\boldsymbol{V}$ and $\boldsymbol{a}$ were found to be meaningless. It has been determined that the $\boldsymbol{V}$ and $\boldsymbol{a}$ parameters on $\mathrm{Ra}$ and $\mathrm{Rz}$ have low effective rates. Unless the $\boldsymbol{a}$ and $\boldsymbol{V}$ values are far outside the recommended values for the tool, it is anticipated that these parameters will not have much effect on the profile roughness value because the measured profile roughness value is a longitudinal measurement result of the axis. 
The greatest effect on the axis length occurs with the $f$. The change in chip depth and $\boldsymbol{V}$ has a transverse effect on the workpiece. Therefore, the amount of feed affects the fluctuation that occurs along a longitudinal line of the workpiece. According to the results of the analysis of the profile roughness values, Ra regression value was obtained as $R^{2}=99.6, R^{2}(\operatorname{adj})=98.5$. It was found that the $\mathrm{R}^{2}$ value was $98.5 \%$ as the $\mathrm{R}^{2}$ value was recalculated by removing the variables that were insignificant from the model. For $\mathrm{Rz}$ value, $\mathrm{R}^{2}$ value was determined as $99.3 \%$, and the Adj SS value as $97.2 \%$. Therefore, the obtained values are close to each other, and high proved the accuracy of the model.

Table 6. ANOVA Results for Taguchi L9 Experiment Design

\begin{tabular}{|c|c|c|c|c|c|c|c|}
\hline \multicolumn{8}{|c|}{ a-ANOVA Results of Ra } \\
\hline Factors & SD & Seq SS & Adj SS & Adj MS & $\mathbf{F}$ & $\mathbf{P}$ & \% Katkı \\
\hline $\mathbf{V}$ & 2 & 0.1355 & 0.1355 & 0.0677 & 0.45 & 0.688 & 0.17 \\
\hline f & 2 & 80.5162 & 80.5162 & 40.2581 & 269.34 & 0.004 & 99.39 \\
\hline $\mathbf{a}$ & 2 & 0.0635 & 0.0635 & 0.0318 & 0.21 & 0.825 & 0.08 \\
\hline Error & 2 & 0.2989 & 0.2989 & 0.1495 & & & 0.37 \\
\hline Total & 8 & 81.0141 & & & & & 100.00 \\
\hline \multicolumn{8}{|c|}{$S=0.3866 R^{2}=\% 99.6 R^{2}(\operatorname{adj})=\% 98.5$} \\
\hline \multicolumn{8}{|c|}{ b- ANOVA Results of $\mathrm{Rz}$} \\
\hline $\mathbf{V}$ & 2 & 0.1696 & 0.1696 & 0.0848 & 0.54 & 0.647 & 0.39 \\
\hline f & 2 & 43.0115 & 43.0115 & 21.5057 & 138.22 & 0.007 & 98.47 \\
\hline $\mathbf{a}$ & 2 & 0.1881 & 0.1881 & 0.0940 & 0.60 & 0.623 & 0.43 \\
\hline Error & 2 & 0.3112 & 0.3112 & 0.1556 & & & 0.71 \\
\hline Total & 8 & 43.6803 & & & & & 100.00 \\
\hline
\end{tabular}

$\mathrm{S}=0.3945 \mathrm{R}^{2}=\% 99.3 \mathrm{R}^{2}(\mathbf{a d j})=\% 97.2$

The 3D surface graph showing the relationship between cutting parameters and surface roughness values ( $\mathrm{Ra}$ and $\mathrm{Rz}$ ) is shown in Figure 2-Figure 4. Figure 2 shows the effect of $\boldsymbol{V}$ and $\boldsymbol{f}$ on the profile roughness values. As the $\boldsymbol{V}$ increases, the temperature in the cutting zone will increase, so chip formation becomes easier and profile roughness improves (Özdemir, 2019; Koçak, 2011). When the literature is examined, it shows that the profile roughness value will increase proportionally with the square of the $f\left(\mathrm{Ra}=0.321 \mathrm{f}^{2} / \mathrm{R}\right)$. It is known that with increasing $f$, the temperature increases due to friction in the cutting area, and the resulting heat concentrates on the tool-chip and tool-workpiece interface (Tekaslan et al., 2008; Öktem et al., 2005; Wang and Feng, 2002; Turgut and Çakmak, 2019; Akkurt, 1998; Demir and Özlü, 2009; Özerkan, 2018). Increasing Ra and Rz values is an expected result since permanent stresses will increase on the treated surface with increasing progress. Minimum profile roughness values were obtained at low $\boldsymbol{f}$ and high $\boldsymbol{V}$ value.
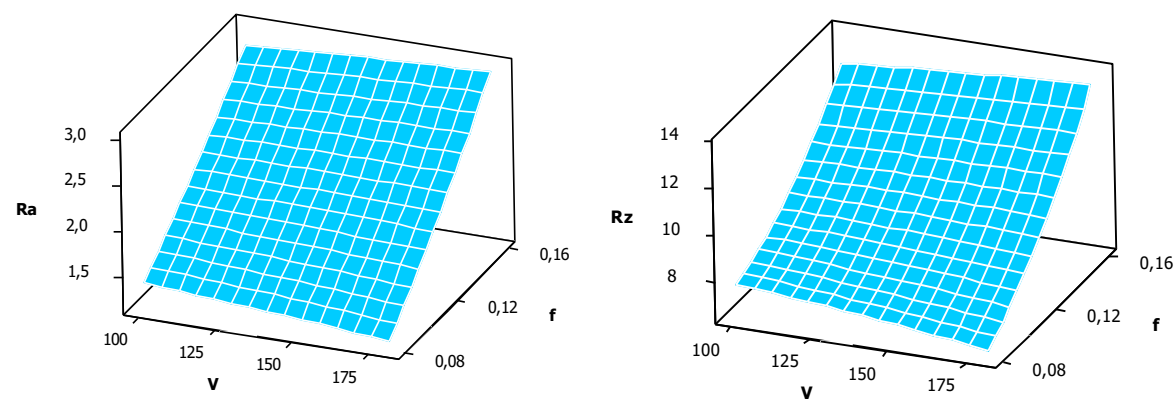

Figure 2. Effects of $\boldsymbol{f}$ and $\boldsymbol{V}$ on profile roughness 

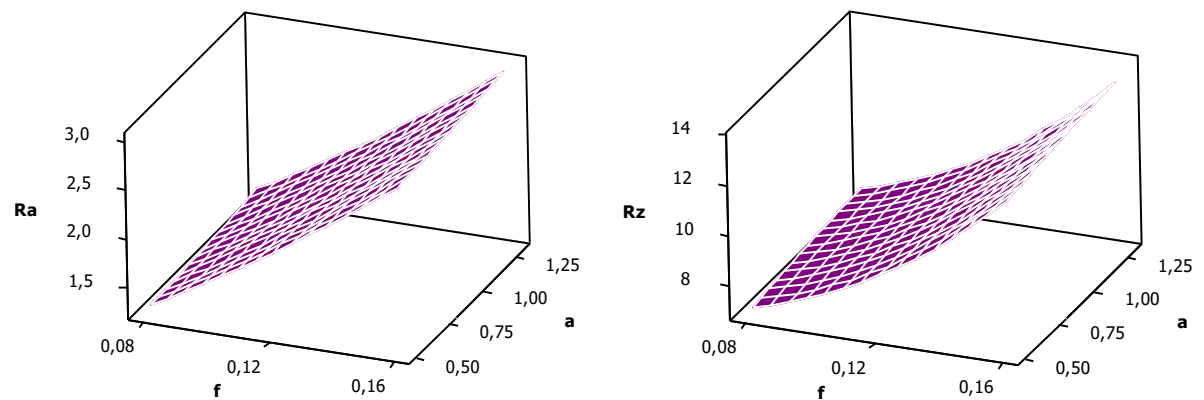

Figure 3. Effects of $\boldsymbol{f}$ and $\boldsymbol{a}$ on profile roughness
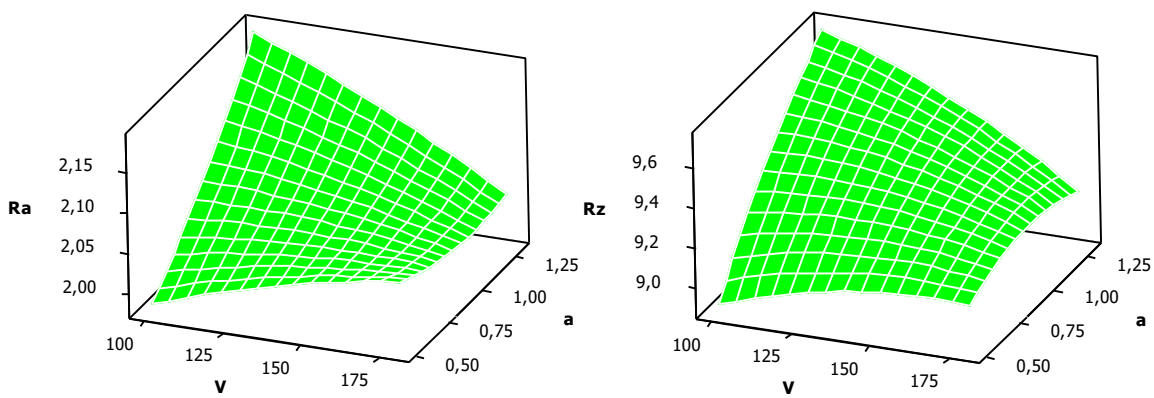

Figure 4. Effects of $\boldsymbol{V}$ and $\boldsymbol{a}$ on profile roughness

With the $\boldsymbol{f}$ - the $\boldsymbol{a}$ (Fig. 3) and $\boldsymbol{V}$ - the $\boldsymbol{a}$ (Fig. 4), the temperature increases in the cutting area, and the cutting tool wears depending on the structure of the cutting tool material. Tool wear causes increased cutting forces and, consequently, increased profile roughness with increased vibration (Özdemir, 2019). With the advance amount and depth of cut pair (Fig. 3), as the $\boldsymbol{V}$ and $\boldsymbol{a}$ (Fig. 4) increase, the temperature increases in the cutting area, and the cutting tool wears depending on the structure of the cutting tool material. Tool wear causes the cutting forces to increase and consequently the profile roughness to deteriorate with increasing vibration.

Using the Taguchi optimization method, the optimal results of profile roughness ( $\mathrm{Ra}$ and $\mathrm{Rz}$ ) values were obtained in the experimental study. By making ANOVA analysis, the effective rates of cutting parameters on the profile roughness value were determined. The final step of the optimization process is to perform verification experiments and test the validity of the optimization process. As a result of Taguchi optimization, the parameter group (V3-f1-a3), which gives the optimal profile roughness value, was obtained. When the results estimated by the verification experiments and the experimental results are compared, it is seen that high convergence values are obtained (Table 7).

Table 7. Comparison of the prediction and experimental results

\begin{tabular}{cccccc}
\hline $\begin{array}{c}\text { Cutting } \\
\text { Parameters }\end{array}$ & Levels & \multicolumn{2}{c}{ Values of $\boldsymbol{R a}(\boldsymbol{\mu m})$} & \multicolumn{2}{c}{ Values of $\boldsymbol{R z}(\boldsymbol{\mu m})$} \\
\hline $\begin{array}{c}\text { Cutting Speed } \\
\text { Feed rate }\end{array}$ & 180 & Prediction & Experimental & Prediction & Experimental \\
Depth of cut & 1.3 & 1.25 & 1.20 & 6.82 & 6.60 \\
\hline
\end{tabular}

In the experimental study conducted, although the feed rate is the most effective parameter on the surface roughness value, some studies have also shown that the cutting speed or depth of cut is more effective. In such studies, the lack of rigidity of the machine tool or the fact that the workpiece is not rigid enough affects the experimental results. In this study, as in many previous studies, it is an expected result that the surface roughness value increases with increasing feed rate. The rigidity of the machine 
tool, the short length of the tool, the connection of the workpiece between the chuck and the tailstock provided a clear view of the effects of cutting parameters on the surface roughness value.

\section{Conclusions}

As a result of turning AISI 4140 steel with TCMT 16T304 NN LT 1000 insert, the Taguchi L9 experiment design was made to determine the effect of $\boldsymbol{V}, \boldsymbol{f}$, and $\boldsymbol{a}$ parameters on the profile roughness value. The test results obtained were analyzed with S/N ratios and RSM. The results obtained after the experiments are given below.

- When S/N ratios are examined, optimum cutting parameters on profile roughness parameters Ra and $\mathrm{Rz}$ are determined at $180 \mathrm{~m} \mathrm{~min}^{-1}$ cutting speed (V3), $0.08 \mathrm{~mm} \mathrm{rev}^{-1}$ feed rate (f1), and $1.3 \mathrm{~mm}$ depth of cut (a3).

- According to ANOVA results, it was determined that the most effective factor on the profile roughness values was the feed rate, while the $\boldsymbol{V}$ and $\boldsymbol{a}$ had a low impact.

- An improvement in profile roughness values was observed with increasing $\boldsymbol{V}$, while a tendency to deteriorate in the quality of the surfaces with an increasing $f$ was detected.

- When the results predicted as a result of the optimization are compared with the experimental results, it was determined that $\mathrm{Ra} 96 \%$ and $\mathrm{Rz} 96.77 \%$ high convergence values were obtained.

\section{REFERENCES}

Akkurt M, 1998. Talaş Kaldırma Yöntemleri ve Takım Tezgâhları. Birsen Yayınevi, İstanbul.

Asiltürk İ, Akkuş H, 2011. Determining the effect of cutting parameters on surface roughness in hard turning using the Taguchi method, Measurement 44:1697-1704.

Asiltürk İ, Çunkaş M, 2011. Modeling and prediction of surface roughness in turning operations using artificial neural network and multiple regression method, Expert Systems with Applications, 38:5826-5832.

Chavoshi SZ, Tajdari M, 2010. Surface roughness modelling in hard turning operation of AISI 4140 using CBN cutting tool, Int J Mater Form 3:233-239.

Daim JP, Gaitonde VN, Karnik SR, 2008. Investigations into the effect of cutting conditions on surface roughness in turning of free machining steel by ANN models, Journal of materials processing technology 205:16-23.

Das SR, Dhupal D, Kumar A, 2015. Study of surface roughness and flank wear in hard turning of AISI 4140 steel with coated ceramic inserts, Journal of Mechanical Science and Technology 29:43294340.

Das SR, Panda A, Dhupal D, 2017. Analysis of surface roughness in hard turning with coated ceramic inserts: Cutting parameters effects, prediction model, cutting conditions optimization and cost analysis, Ciência e Técnica Vitivinícola 32:127-154.

Demir H, Özlü B, 2009. Sertleştirilmiş 30MnVS6 mikroalaşımlı çeliğin kesme kuvvetleri ve yüzey pürüzlülüğü açısından işlenebilirliğinin araştırılması. Erciyes Üniversitesi Fen Bilimleri Enstitüsü Dergisi 25:262-271.

Gür AK, Taşkaya S, Özay Ç, 2019. Ramor 500 Çeliğinde Isıl İşlemin Mikroyapı, Mikrosertlik ve Abrasiv Aşınma Direncine Etkisinin Taguchi Metoduyla Değerlendirilmesi, BEÜ Fen Bilimleri Dergisi 8:1045-1056.

Günay M, 2013. AISI 316L çeliğinin işlenmesinde takım radyüsü ve kesme parametrelerinin Taguchi yöntemiyle optimizasyonu. Gazi Üniversitesi Mühendislik Mimarlık Fakültesi Dergisi, 28:437444. 
Hessainia Z, Belbah A, Yallese MA, Mabrouki T, Rigal JF, 2013. On the prediction of surface roughness in the hard turning based on cutting parameters and tool vibrations, Measurement 46:1671-1681.

Koçak H, 2011. GGG 90 Küresel Grafitli Dökme Demirin İşlenebilirliğinin Kesme Kuvvetleri Yüzey Pürüzlülüğü ve Takım Aşınması Açısından Değerlendirilmesi, Gazi Üniversitesi Fen Bilimleri Enstitüsü, M. Sc. Thesis, Ankara.

Motorcu AR, Işık Y, Kuş A, Çakır MC, 2016. Analysis of The Cutting Temperature and Surface Roughness During The Orthogonal Machining of AISI 4140 Alloy Steel Via The Taguchi Method, Materials and technology 50:343-351.

Nalbant M, Gökkaya H, Sur G, 2007. Application of Taguchi method in the optimization of cutting parameters for surface roughness in turning, Materials and Design 28:1379-1385.

Öktem H, Erzurumlu T, Kurtaran H, 2005. Application of response surface methodology in the optimization of cutting conditions for surface roughness. Journal of Materials Processing Technology 170:11-16.

Özdemir M, 2019. Optimization with Taguchi Method of Influences on Surface Roughness of Cutting Parameters in CNC Turning Processing, Mechanika 25:397-405.

Özel T, Karpat Y, 2005. Predictive modeling of surface roughness and tool wear in hard turning using regression and neural networks, International Journal of Machine Tools \& Manufacture 45:467479.

Özerkan H, 2018. Tornada Oluşan Yüzey Pürüzlülüğünün Yorulma Ömrüne Etkisinin Teorik Değerlendirilmesi. Çukurova Üniversitesi Mühendislik-Mimarlık Fakültesi Dergisi 33:189-198.

Reis BCM, Santos JDS, Santos NFPD, Camara MA, Faria PE, Abrao AM, 2019. Cutting performance and wear behavior of coated cermet and coated carbide tools when turning AISI 4340 steel, The International Journal of Advanced Manufacturing Technology 105:1655-1663.

Ross PJ, 1988. Taguchi Techniques for Quality Engineering, Mc-Graw-Hill, New York

Savas V, Ozay C, Ballikaya H, 2016. Experimental investigation of cutting parameters in machining of 100Cr6 with tangential turn-milling method. Adv. Manuf. 4:97-104.

Shaw MC, 1984. Metal Cutting Principles, Oxford University Press Oxford.

Suresh R, Basavarajappa S, Gaitonde VN, Samuel GL, 2012. Machinability investigations on hardened AISI 4340 steel using coated carbide insert, Int. J. Refract. Metals Hard Mater. 33:75-86.

Şahinoğlu A, Rafighi M, 2020. Investigation of Vibration, Sound Intensity, Machine Current and Surface Roughness Values of AISI 4140 During Machining on the Lathe, Arabian Journal for Science and Engineering 45:765-778.

Tekaslan Ö, Gergen N, Şeker U, 2008. CNC torna tezgahında AISI 304 çeliklerin işlenemesinde optimum yüzey pürüzlülüğünü sağlayacak kesme parametrelerinin tespiti. Dumlupınar Üniversitesi Fen Bilimleri Enstitüsü Dergisi 16:97-104.

Turgut Y, Çakmak I, 2019. Investigation of the Effect of Chip Breaker Form on Surface Roughness and Cutting Forces in AISI 1040 Steel Milling. GU J Sci, Part C 7:482-494.

Yadav UK, Narang D, Attri PS, 2012. Experimental Investigation and Optimization of Machining Parameters for Surface Roughness In CNC Turning By Taguchi Method. International Journal of Engineering Research and Applications 2:2060-2065.

Wang X, Feng CX, 2002. Development of empirical models for surface roughness prediction in finish turning. The International Journal of Advanced Manufacturing Technology 20:348-356. 